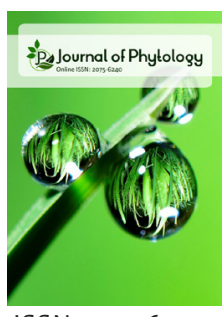

ISSN: $2075-6240$

\title{
Response of morphological and biochemical traits of maize genotypes under waterlogging stress
}

\author{
Shamima Nasrin Asha, Naima Sultana, Lutful Hassan, Shirin Akhter, \\ Arif Hasan Khan Robin * \\ Department of Genetics and Plant Breeding, Bangladesh Agricultural University, Mymensingh-2202, Bangladesh
}

\begin{abstract}
Maize (Zea mays L.) is one of the most important cereal crops cultivated around the world. Waterlogging stress is a major production constraint of maize production in rain-fed agricultural systems. The main objective of this experiment was to investigate the effect of continuous waterlogging on morphological and biochemical traits of maize genotypes at the vegetative stage. Ten maize genotypes were treated under no waterlogging (control) and continuous waterlogging of five centimeters depth for 10 days. The treatments were applied to the plants at their 45 days of age. Visual leaf injury scores from Leaf 4 (youngest leaf is the reference point) to Leaf 7 separated tolerant and susceptible genotypes. Waterlogging stress significantly reduced the total number of live leaves and chlorophyll content in leaf tissues in susceptible genotypes. The anatomical study revealed that tolerant maize genotypes produce a large number of aerenchyma cells under waterlogging stress compared to susceptible genotypes. The enzymatic activities of ascorbate peroxidase (APX) and peroxidase (POD) exhibited a greater increase in tolerant genotypes than susceptible genotypes whereas the contents of reactive oxygen species $\left(\mathrm{H}_{2} \mathrm{O}_{2}\right)$ greatly increased in susceptible genotypes than tolerant genotypes under waterlogging stress compared to control. Principal component 2 (PC2) indicated that increasing plant height in the genotypes BHM-14, BHM-13 and BHM-9 was associated with waterlogging tolerance. The findings of this experiment will add value to maize breeding to screen out maize genotypes for waterlogging stress tolerance.
\end{abstract}

*Corresponding author:

Arif Hasan Khan Robin,

E-mail: gpb21bau@bau.edu.bd

KEYWORDS: Zea mays L., waterlogging, morphology, biochemical traits

\section{INTRODUCTION}

Maize (Zea mays L.) is called the queen of the cereals due to its high productivity, wider adaptability in the various agroecological regions and high genetic potential compared to other cereals (Mahesh et al., 2013). Maize is one of the most widely produced and consumed crops in the world by producing about 1116.2 million metric tons in 2019-2020 (USDA, www.fas. usda.gov/data/grain-world-markets-and-trade). In recent years, abiotic stresses such as drought, waterlogging, submergence, salinity and extreme temperature are increasingly affecting crop production and productivity (Bray et al., 2000).

Waterlogging has become one of the main constraints of maize production worldwide by affecting its yield performance (Du et al., 2017). The main causes of waterlogging in maize production are-continuous rainfall with inadequate drainage, contingent flooding, and high water-table. Sometimes maize is grown in converted paddy fields or in poorly drained soil that help create waterlogging during the rainy season (Amin et al., 2014). In the
Asian monsoon regions, the main source of waterlogging stress of the summer maize is flooding of fields during late spring and summer (Mano et al., 2006). Over 18\% of total maize growing areas in the South and South-East Asia are frequently affected by waterlogging stress (Zaidi et al., 2009). The agronomic and yield performance of maize is severely affected by waterlogging stress (Osman et al., 2013). Extinction of plant species and alteration of plant distribution can be caused by extreme or gradual waterlogging (Bailey-Serres \& Voesenek, 2008).

Waterlogging causes a reduction of gas exchange between the atmosphere and root tissue by 100 times lowering the diffusion rate of gases in the flooded soil (Zaidi et al., 2009). Waterlogging condition decreases the available $\mathrm{O}_{2}$ for plants (Capon et al., 2009). With the gradual decrease of oxygen, plant root suffers from hypoxia (low oxygen) followed by anoxia (no oxygen) when faced with excess moisture for more than three days (Dennis et al., 2000; Zaidi and Singh, 2002). Some physiological processes of plants that require oxygen - including growth and cell division, uptake and

Copyright: $\odot$ The authors. This article is open access and licensed under the terms of the Creative Commons Attribution License (http://creativecommons.org/licenses/by/4.0/) which permits unrestricted, use, distribution and reproduction in any medium, or format for any purpose, even commercially provided the work is properly cited. Attribution - You must give appropriate credit, provide a link to the license, and indicate if changes were made. 
transpiration of nutrients and respiration-become affected under waterlogging. Plants growth, development and survival are dramatically affected by waterlogging conditions (Parent et al., 2008). However, the level of damage significantly depends on the developmental stages of the crop. From the early seedling stage to tasseling stage are the susceptible stages of maize under waterlogging (Zaidi et al., 2004). Plants suffer from chlorosis, necrosis, decreased growth, defoliation, yield loss and eventually plants die due to waterlogging stress (Hasanuzzaman et al., 2016).

Plants under waterlogging conditions survive through various morphological, physiological, anatomical and biochemical adaptations. Production of ethylene and formation of adventitious roots are some of the major adaptive responses under waterlogging stress due to $\mathrm{O}_{2}$ deficiency (Pezeshki, 2001; Suralta and Yamauchi, 2008). Under waterlogging conditions, the plant exhibits several anatomical changes by the formation of gas space or aerenchyma. The presence of the aerenchyma or gas space is the most common adaptive feature for the distribution and flow of oxygen from root to shoot under waterlogging stress (Colmer \& Voesenek, 2009; Shiono et al., 2011). Reduction of soil redox potential and enhancement of generation of toxic compounds occur due to waterlogging (Fiedler et al., 2007). Production of active oxygen species (AOS) such as superoxide $\left(\mathrm{O}_{2}^{-}\right.$.), singlet oxygen $\left({ }^{1} \mathrm{O}_{2}\right)$, hydrogen peroxide $\left(\mathrm{H}_{2} \mathrm{O}_{2}\right)$ and hydroxyl radicals $(\mathrm{OH} \bullet$ ) are the results of oxidative stress due to waterlogging (Subbaiah \& Sachs, 2003; Liao \& Lin, 2003; Zhang et al., 2003; Jackson $\&$ Colmer, 2005). Due to normal aerobic metabolism, AOS is present in plants at different levels and contribute to waterlogging damage vitally (Kuk et al., 2003). AOS is highly reactive and therefore any oxidative damage to lipids, proteins and nucleic acids can change normal cellular metabolism (McKersie \& Leshem, 1994; Alscher et al., 1997; Imlay, 2003; de Azevedo Neto et al., 2006). However, plants have the potential to detoxify the adverse effects of reactive oxygen species (ROS) by generating various forms of antioxidants such as ascorbate peroxidase (APX), superoxide dismutase (SOD), peroxidase (POD), catalase (CAT), glutathione reductase (GR), ascorbic acid, glutathione, tocopherols and carotenoids (Biswas \& Kalra, 2018). In addition, significant genetic variability in the tolerance of maize to water-logging stress has been reported (Zaidi et al., 2002, 2003, 2007).

Response of morpho-physiological traits associated with tolerance and identification of promising genotypes of maize are the prerequisite for the success of breeding under waterlogging stress. Identification and development of genotypes capable of withstanding water logging conditions could be an ideal and affordable approach, which could be suitable for maizegrowing farmers lacking sufficient resources in the sub-tropics. The major bottlenecks are the lack of appropriate screening techniques, morpho-physiological traits associated with tolerance and the identification of promising genotypes (Zaidi \& Singh, 2001). Therefore, it is important to run an experiment to assess the response of morphological and biochemical traits of maize genotypes under water-logging. The objective of this study was to find out traits of maize genotypes responsive to waterlogging stress at morphological and biochemical levels that may offer tolerance under stress conditions.

\section{MATERIALS AND METHODS}

\section{Plant Materials and Growth Conditions}

Seeds of ten selected maize genotypes were collected from Bangladesh Agricultural Research Institute (BARI), Gazipur-1700 (Table 1). The experiment was laid out following a Randomized Complete Block Design (RCBD) with three replications. There were two treatments-no water (control) and $5.0 \mathrm{~cm}$ water treated plot (Figure 1). A waterlogging treatment was applied in the field continuously for 10 days with an average depth of $5.0 \pm 1.0 \mathrm{~cm}$ at the vegetative stage of plant in order to introduce stress when the plants were 45 days old. Water level of the treated field was maintained continuously at the same level throughout the experiment from one end to another end of the plots.

\section{Measurements and Data Collection}

\section{Morphological traits analysis}

Leaf scoring

Leaves of ten genotypes from both control and waterloggingtreated plants were scored based on injury level using 1-9 scores at 10 days after application of waterlogging stress (Figure 2, Table 2, Arif et al., 2019).

Plant height

Plant height of individual plants was measured at 3, 6 and 9 days after treatment imposition. The measurement of plant height was carried out in centimeters $(\mathrm{cm})$ from the soil surface to the highest point of the arch of the uppermost leaf whose tip is pointing down.

Leaf area

The length and width of each leaf was measured individually at 3 , 6 and 9 days after treatment and the area of individual leaf laminae was estimated using the following formula: $\mathrm{LA}=0.75 \times$ Leaf Length $\times$ Leaf Width (Ren et al., 2013). Leaf area of the individual leaves was added to estimate the total leaf area of each plant.

Number of live leaves (NLL)

At 3, 6 and 9 days after applying waterlogging stress, the live leaves per plant were counted. A leaf was considered as an alive leaf when more than $50 \%$ of its leaf area was green.

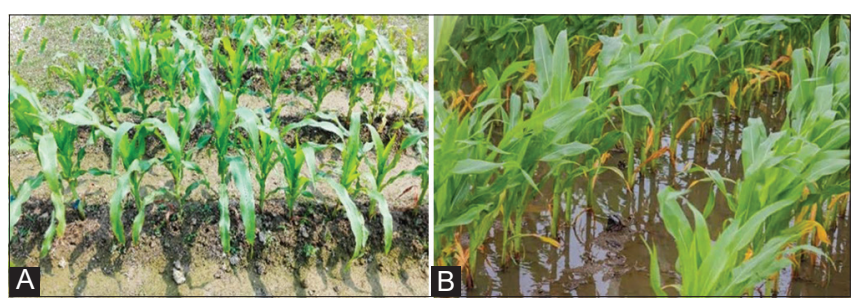

Figure 1: Experimental plot (A) control plot (no waterlogging) (B) treated plot (waterlogging) 
Table 1: List of ten maize genotypes used in this study with their characteristics (DHCP, 2017, BARI, http://baritechnology.org/ en/ home/tech commodity\# result). BARI, Bangladesh Agricultural Research Institute

\begin{tabular}{|c|c|c|c|c|c|c|}
\hline Genotypes & Given identity & $\begin{array}{l}\text { Developed } \\
\text { by }\end{array}$ & Growing season & $\begin{array}{l}\text { Average yield } \\
\text { (t ha-1) }\end{array}$ & Year of release & Characteristics \\
\hline BHM-14 & G1 & BARI & Rabi, kharif & $\begin{array}{l}\text { Rabi } 10.84 \\
\text { Kharif } 10.52\end{array}$ & 2017 & $\begin{array}{l}\text { Early maturing, high temperature tolerant, root and } \\
\text { stalk lodging tolerant }\end{array}$ \\
\hline BHM-9 & G2 & BARI & Rabi, kharif & $\begin{array}{l}\text { Rabi 10.0-11.0 } \\
\text { Kharif } 7-7.5\end{array}$ & 2007 & Higher yield potential, resistant to disease and pest \\
\hline Popcorn & G3 & BARI & Rabi, kharif & $\begin{array}{l}\text { Rabi } 5.5 \\
\text { Kharif } 4.0-4.5\end{array}$ & 1986 & High poping quality (95\%) \\
\hline $\mathrm{BHM}-13$ & G4 & BARI & - & - & 2016 & - \\
\hline $\mathrm{BHM}-7$ & G5 & BARI & Rabi, kharif & $\begin{array}{l}\text { Rabi 10.0-11.0 } \\
\text { Kharif } 7-7.5\end{array}$ & 2006 & Higher yield potential, resistant to disease and pest \\
\hline BHM-12 & G6 & BARI & - & - & 2016 & - \\
\hline BM-6 & G7 & BARI & Rabi, kharif & $\begin{array}{l}\text { Rabi } 6.5-7.5 \\
\text { Kharif } 5.0-6.0\end{array}$ & 1998 & High yield potential, resistant to disease and pest \\
\hline BM-7 & G8 & BARI & Rabi, kharif & $\begin{array}{l}\text { Rabi } 6.5-7.5 \\
\text { Kharif } 5.0-6.0\end{array}$ & 2002 & Open pollinated variety, high yield, bold grain \\
\hline Mohor & G9 & BARI & Rabi, kharif & $\begin{array}{l}\text { Rabi } 5.0-5.5 \\
\text { Kharif } 3.5-4.5\end{array}$ & 1991 & High yield \\
\hline Barnali & G10 & BARI & Rabi, kharif & $\begin{array}{l}\text { Rabi 5.5-6.0 } \\
\text { Kharif } 4.0-4.5\end{array}$ & 1986 & High yield, resistant to pest and disease \\
\hline
\end{tabular}

Table 2: Scoring criteria for the visual injury scoring under waterlogging stress at the vegetative stage for ten maize genotypes

\begin{tabular}{ll}
\hline Score & Leaves \\
\hline 1 & $\begin{array}{l}\text { Normal color and growth } \\
3\end{array}$ \\
$\begin{array}{l}\text { Nearly normal condition, but leaf tip become discolored and } \\
\text { wilting started }\end{array}$ \\
$\begin{array}{l}\text { Leaf become rolled, most part of the leaf become discolored and } \\
\text { started drying }\end{array}$ \\
$\begin{array}{l}\text { Leaf become mostly dry, totally discolored } \\
\text { Leaf dead or near to die }\end{array}$
\end{tabular}

Percent leaf (\%) mortality rate

Percent leaf mortality rate was estimated by counting total number of dead leaves (less than $50 \%$ alive) and the total number of live leaves (more than $50 \%$ alive) per plant at 9 days after applying the waterlogging stress and percent mortality was counted by using the following formula:

$\begin{aligned} & \text { Leaf mortality } \\ & \text { rate }(\%)=\end{aligned} \frac{\text { Number of dead leaves/plant }}{\text { Total number of leaves/plant }} \times 100$

Chlorophyll content

At 9 days after applying waterlogging stress, the chlorophyll content of the $3^{\text {rd }}$ leaf of each plant was measured with the help of a chlorophyll meter (SPAD-502 PLUS, 3V=200 Mw, Konica Minolta, Osaka, Japan). This was done similarly for each plant under control and waterlogging treatment. It was a nondestructive method. There is a small sensor inside the meter and leaves were placed between them. For each leaf three positions (proximal, distal and middle) were brought under measurement and the measurements were averaged (Abbasi et al., 2015).

\section{Anatomical study}

During the experimentation, $0.5 \%$ acetocarmine solution was used for staining roots. To prepare the solution $0.5 \mathrm{~g}$ carmine

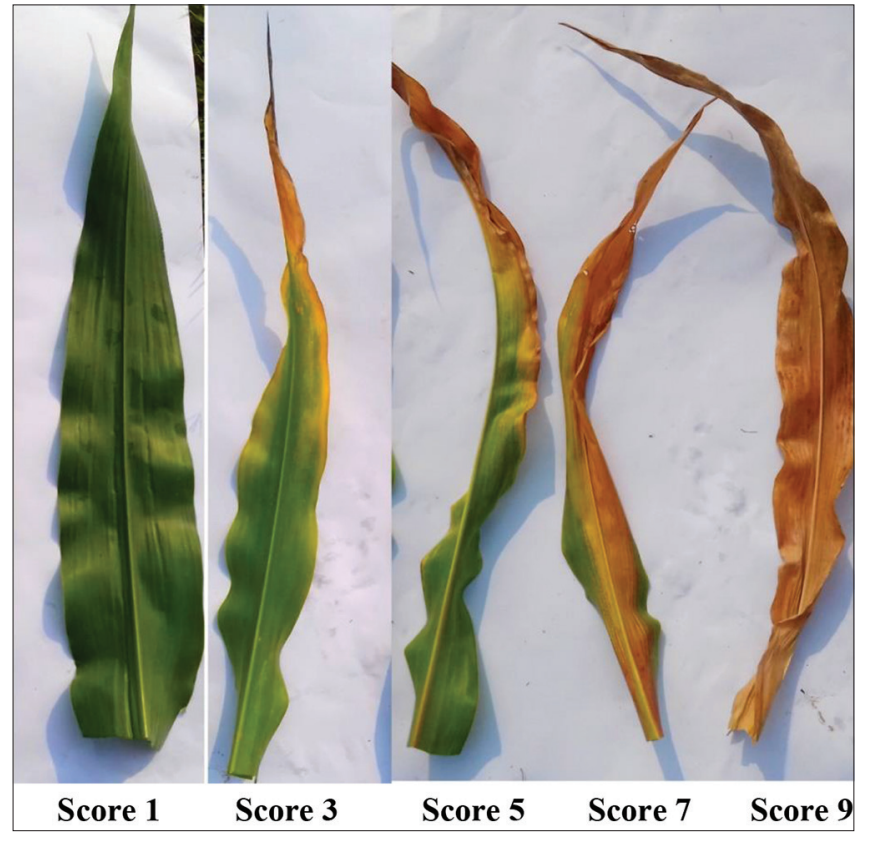

Figure 2: Leaf injury scores of leaves of maize genotypes under waterlogging treatment

was dissolved in $100 \mathrm{~L}$ of $45 \%$ glacial acetic acid, and refluxed for 24 hours (KSU, 2018). The dissected roots were stained with $0.5 \%$ acetocarmine well enough to visualize under a microscope. The cross-sections of roots were visualized at 100x magnification and the root anatomical structure was captured.

\section{Biochemical trait analysis}

Leaf samples from the $4^{\text {th }}$ youngest leaf of four selected genotypes (BHM-9, BHM-13, BM-6 and Popcorn) were collected at 10 days after waterlogging stress and were subjected for biochemical analysis. The ascorbate peroxidase (APX) and peroxidase (POD) activities were determined by following the method of Nakano and Asada (1981). Hydrogen peroxide 
$\left(\mathrm{H}_{2} \mathrm{O}_{2}\right)$ activity was determined by following the protocol of Velikova et al. (2000).

\section{Statistical Analysis}

Data were analyzed using MINITAB 17 statistical software packages (Minitab Inc., State College, Pennsylvania, USA). A two-way analysis of variance (ANOVA) was executed for different morphological and biochemical traits following a general linear model (GLM) to explore treatment, genotype and treatment genotype interaction. Principal Component Analysis (PCA) of the morphological traits was carried out to investigate the association between morphological traits and tolerance of genotypes under treatment. The Principal Component (PC) scores were stored and ANOVA of the PC scores was performed following a one way ANOVA to explore the statistical significance between treatment and genotypes and treatment-variety interaction.

\section{RESULTS}

\section{Treatment Effect}

Waterlogging stress significantly affected the survivability of older leaves exhibiting genotypic variations (Table 2, Figure 3). The number of leaves per plant ranged between 8 and 11 in maize genotypes under both control and waterlogging treatment during data collection. The first three young leaves were fully alive (score 1) showing no sign of injury under both control and waterlogging treatments (Table 2). On the other hand, leaf injury scores from the leaf position 7 to leaf position 9 were nine for all genotypes under waterlogging treatment although that ranged between 1 and 3 under control treatment. Notably, the leaf injury scores of leaf position 4-6 of 10 maize genotypes under waterlogging treatment showed notable variations among genotypes (Figure 3). The genotypes BHM-14, BHM-13 and Barnali accounted for leaf injury scores lower than 3 up to leaf position 5 and that of lower than 5 up to leaf position 6 (Figure 3). These three genotypes were therefore graded as tolerant. The genotypes BHM-9, BHM-12 and Mohor accounted for leaf injury scores 5 at both leaf positions 5 and 6 (Figure 3). These three genotypes were graded as moderately tolerant (Figure 3). The four other genotypes, Popcorn, BHM-7, BM-6 and BM-7 accounted for leaf injury scores higher than 5 at the leaf position 6 (Figure 3). These four genotypes were graded as susceptible (Figure 3).

Waterlogging stress significantly altered the morphological traits of maize plants including plant height, number of live leaves, mortality rate of leaves, leaf area and chlorophyll content (Figure 4, Figure S1-S7). Plant height was significantly increased by 1.35 folds $(P=0.006)$ for BHM-9 at 3 days after waterlogging stress compared to control (Figure S1). Plant height at 6 days after waterlogging increased by 1.31 folds $(P<0.001)$ in genotype BHM-9 under waterlogging stress compared to control (Figure S2). The total number of live leaves was decreased by 1.26 folds $(P<0.001)$ in BM-6 at

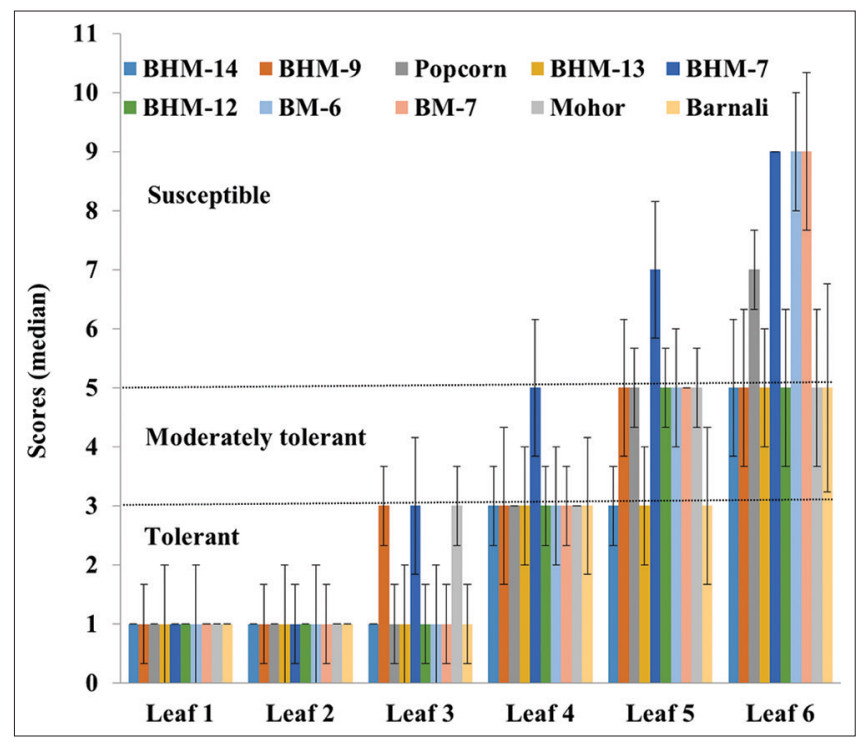

Figure 3: Median values of leaf injury scores of six young leaves of 10 maize genotypes after 10 days of waterlogging considering the youngest leaf as leaf 1 . Vertical bars indicate standard error of mean. Median leaf injury scores of all genotypes in control plants were 1

6 days after waterlogging treatment compared to control (Figure S5). The total number of live leaves was decreased from 1.3 to 1.4 folds $(P<0.001)$ in genotypes BHM-13, BHM7, BHM-12, BM-6, BM-7, Mohor and Bornali at 9 days after waterlogging treatment compared to control (Figure 4A). Percent leaf mortality rate (\%MR) was increased by 5.12 folds in genotype BHM-12 followed by 4.69 folds in genotype BHM$13(P<0.001)$ under waterlogging treatment compared to control (Figure 4B). The genotypes BHM-14, Popcorn, BHM-7 showed a reduction in chlorophyll content (CC) by 1.15, 1.58, 2.27 folds $(P<0.001)$, respectively, under waterlogging stress compared to control (Figure 4C).

\section{Response of Biochemical Traits Under Waterlogging Stress}

The contents of APX and POD were increased in both tolerant and susceptible genotypes under waterlogging stress compared to control (Figure 5A) but their contents were greatly increased in two tolerant genotypes BHM-9 and BHM-13 compared to two susceptible genotypes, Popcorn and BM-6 (Figure 5A). The content of APX was increased by 3.67 folds $(P<0.001)$ in the moderately tolerant genotype BHM- 9 followed by 2.33 folds in the tolerant genotype BHM-13 (Figure 5A) whereas the content of POD was increased by 2.46 folds $(P<0.001)$ in tolerant genotype $\mathrm{BHM}-13$ under waterlogging treatment compared to control (Figure 5B).

The content of hydrogen peroxide $\left(\mathrm{H}_{2} \mathrm{O}_{2}\right)$ as a measure of oxidative stress greatly increased in both susceptible genotypes Popcorn and BM-6 but that was decreased on tolerant genotype BHM-9 but slightly increased in BHM-13 (Figure 5C). The highest increase in the content of $\mathrm{H}_{2} \mathrm{O}_{2}$ by 9.05 folds was observed in susceptible genotype BM-6 under waterlogging stress compared to control (Figure 5C). 


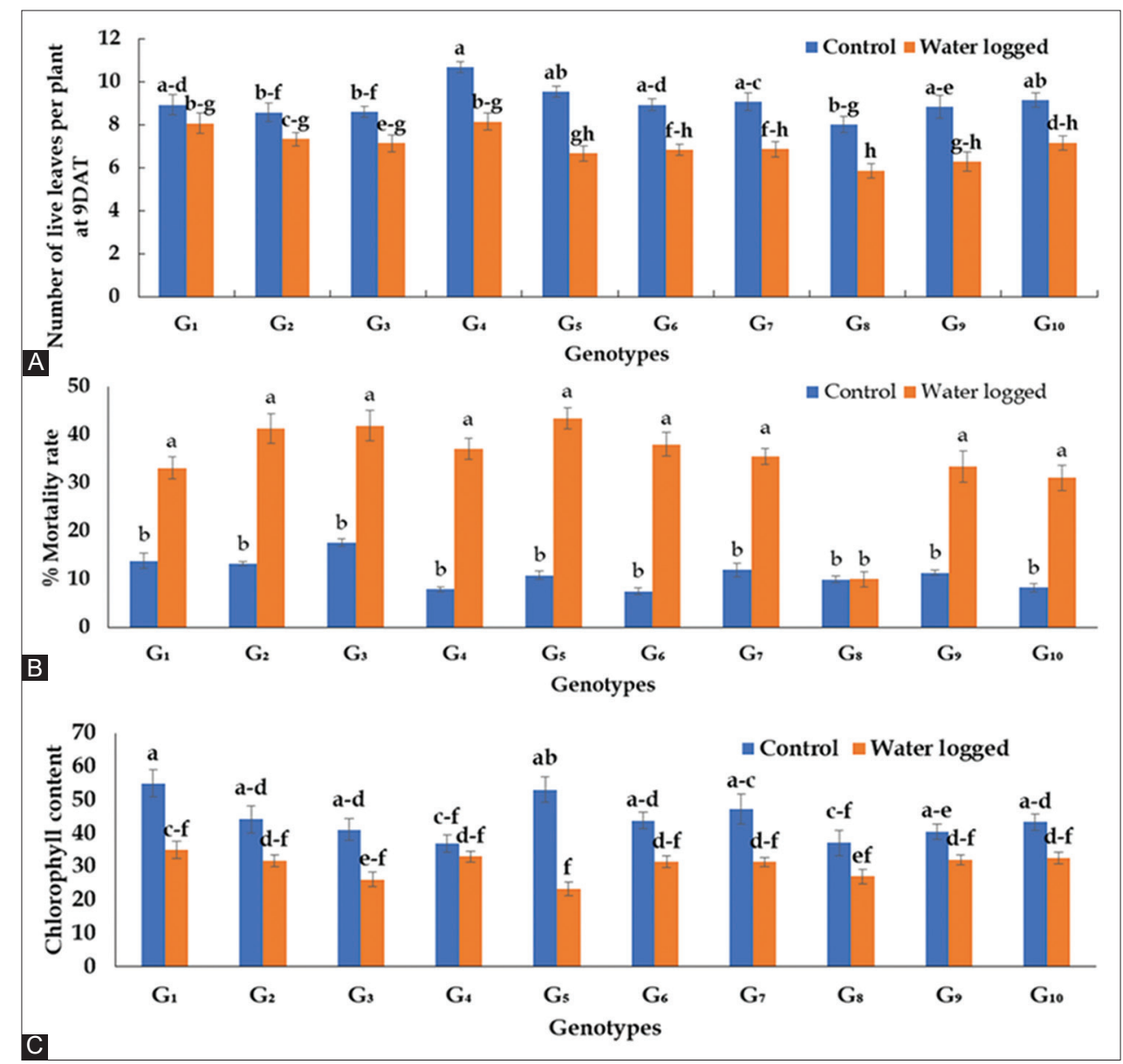

Figure 4: Treatment effect, genotypic variation and treatment $\times$ genotype interaction for (A) total number of live leaves (B) \% leaf mortality rate (C) chlorophyll content at nine days after waterlogging stress of ten maize genotypes under control and waterlogging treatments. Vertical bars indicate standard error of mean; different letters indicate significant difference among the treatment $\times$ genotype interaction. In the graph, $\mathrm{G} 1=$ BHM-14, G2= BHM-9, G3= Popcorn, G4= BHM-13, G5= BHM-7, G6= BHM-12, G7= BM-6, G8= BM-7, G9= Mohor, G10= Barnali

\section{Genotype Difference}

A remarkable number of morphological traits exhibited significant genotypic variation including plant height at 3,6 and 9 days after waterlogging, number of live leaves at 3,6 and 9 days after waterlogging, percent leaf mortality rate (\%MR), chlorophyll content (CC), leaf area at 3, 6 and 9 days after waterlogging (Table $\mathrm{Sl}$ ). The content of hydrogen peroxide $\left(\mathrm{H}_{2} \mathrm{O}_{2}\right)$, peroxidase (POD) and ascorbate peroxidase (APX) also showed a significant varietal difference (Suppl. Table 1).

\section{Anatomical Difference}

Maize genotypes under control condition (no waterlogging) produce no aerenchyma cells in epidermal regions (Figure 6A). Anatomical study showed that roots of tolerant maize genotypes such as BHM-13, BHM-14 and Barnali under waterlogging stress produced large aerenchyma cells (Figure 6B). By contrast, the susceptible maize genotypes such as BHM-7, BM-6 and BM-7 produced aerenchyma cells either none or comparatively much lower in number compared to tolerant genotypes under waterlogging stress (Figure 6B vs. 6C).

\section{Trait Association}

\section{Principal component analysis (PCA)}

The first three principal components (PC) explained $72 \%$ of the total data variation that showed variation due to the effect of waterlogging and genotypes (Table 3). The first principal component (PCl) explained $40.9 \%$ variation, second principal component (PC2) explained $19.6 \%$ and third principal component (PC3) explained 12\% variation (Table 3). Scores of $\mathrm{PCl}$ were highly significant for treatment (waterlogging), genotype and treatment-genotype interaction (Table 3). PC2 showed that PC scores were highly significant for treatment, genotype and treatment-genotype interaction. PC3 scores were highly significant for genotype and genotype treatment interaction (Table 3).

The PCl separated the genotype BHMl4 (Gl) from the genotype BM7 (G8) for their highest positive and negative PC scores, respectively (Figure 7). PCl also accounted for higher coefficients for a number of live leaves per plant and plant height (Figure 7). PC2 separated genotypes based on control versus waterlogging stress for their positive and negative 
scores, respectively (Figure 7). Plant height at 3 days after waterlogging, plant height at 6 days after waterlogging and plant height at 9 days after waterlogging treatments also had negative coefficients for $\mathrm{PC} 2$ indicating that the genotypes BHMl4 (G1), BHM 9 (G2) and popcorn (G3) were the least affected under waterlogging stress and thus exhibited higher stress tolerance (Figure 7).

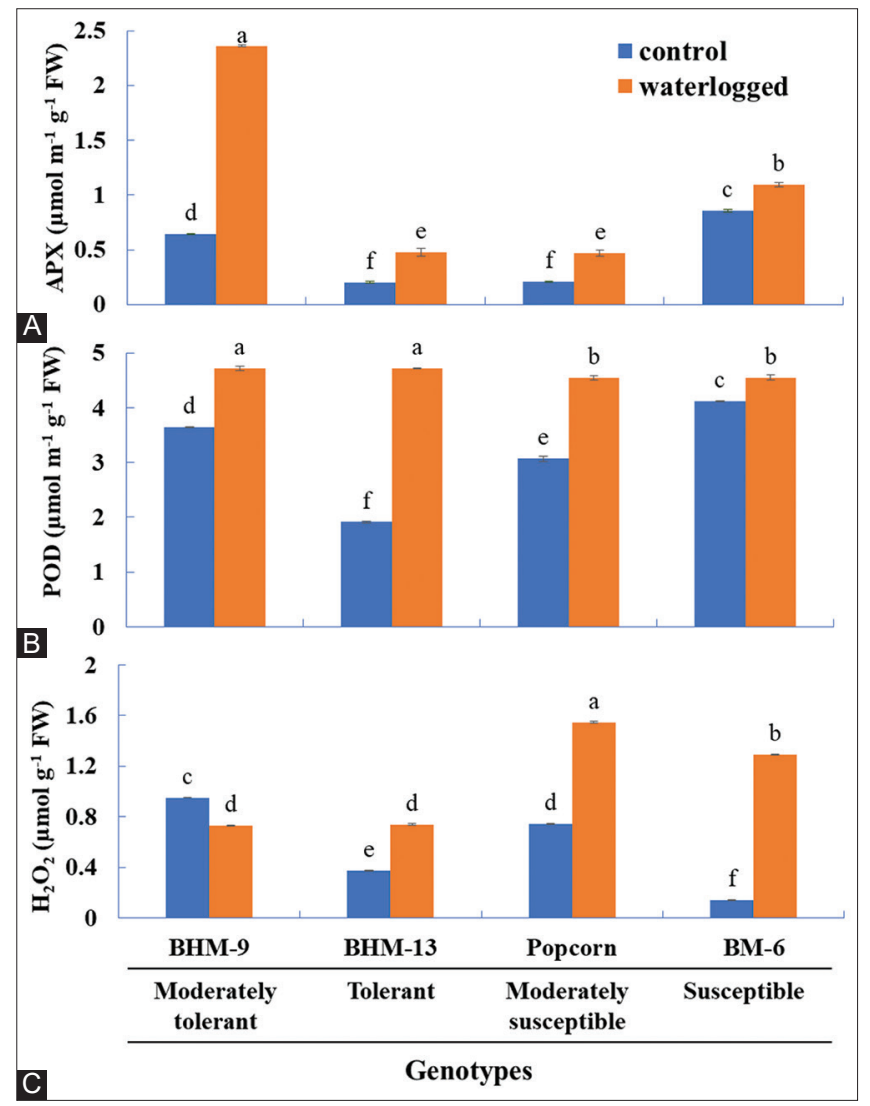

Figure 5: Treatment effect, genotypic variation and treatment $x$ genotype interaction for (A) APX (B) POD and (C) $\mathrm{H}_{2} \mathrm{O}_{2}$ of four selected maize genotypes under control and waterlogging treatments. Vertical bars indicate standard error of mean; different letters indicate significant difference among the treatment $\times$ genotype interaction

\section{DISCUSSION}

This study was conducted to investigate the response of morpho-physiological traits of maize genotypes under waterlogging conditions. The increasing trend of plant height of a few maize genotypes along with the response of biochemical traits under waterlogging are discussed herein.

\section{Impact of Waterlogging on Morphological Traits}

\section{Plant height}

According to Parent et al. (2008), the height of the plant and the height of the ear in maize were severely affected in almost all genotypes. In contrast, Li et al. (2011) concluded that waterlogging did not significantly affect plant height. In the present study, significant differences in plant height under waterlogging and significant varietal interaction indicated that selection for waterlogging tolerance could be effective (Figure S1-S3).

Table 3: Principal components and their coefficients from principal component analysis

\begin{tabular}{lccc}
\hline Variable & PC1 & PC2 & PC3 \\
\hline Plant height (cm) 3DAT & 0.361 & -0.381 & 0.032 \\
Plant height (cm) 6DAT & 0.383 & -0.353 & 0.062 \\
Plant height (cm) 9DAT & 0.404 & -0.291 & 0.086 \\
No. of live leaves 3DAT & 0.369 & -0.11 & -0.211 \\
No. of live leaves 6DAT & 0.39 & 0.19 & -0.243 \\
No. of live leaves 9DAT & 0.361 & 0.329 & -0.238 \\
Mortality rate & -0.179 & -0.551 & 0.102 \\
Chlorophyll Content & 0.264 & 0.381 & 0.13 \\
Leaf area 3DAT & 0.134 & 0.117 & 0.535 \\
Leaf area 6DAT & 0.085 & 0.064 & 0.548 \\
Leaf area 9DAT & 0.116 & 0.151 & 0.462 \\
\%variation explained & 40.9 & 19.6 & 12 \\
Source of variation & & $P$ value for PC score & \\
\hline Treatment & $<0.001$ & $<0.001$ & 0.603 \\
Genotype & $<0.001$ & $<0.001$ & $<0.001$ \\
Treatment x Genotype & 0.041 & $<0.001$ & $<0.001$ \\
\hline
\end{tabular}

P-Probability of statistical significance; PC - principal component; DAT - days after transplanting

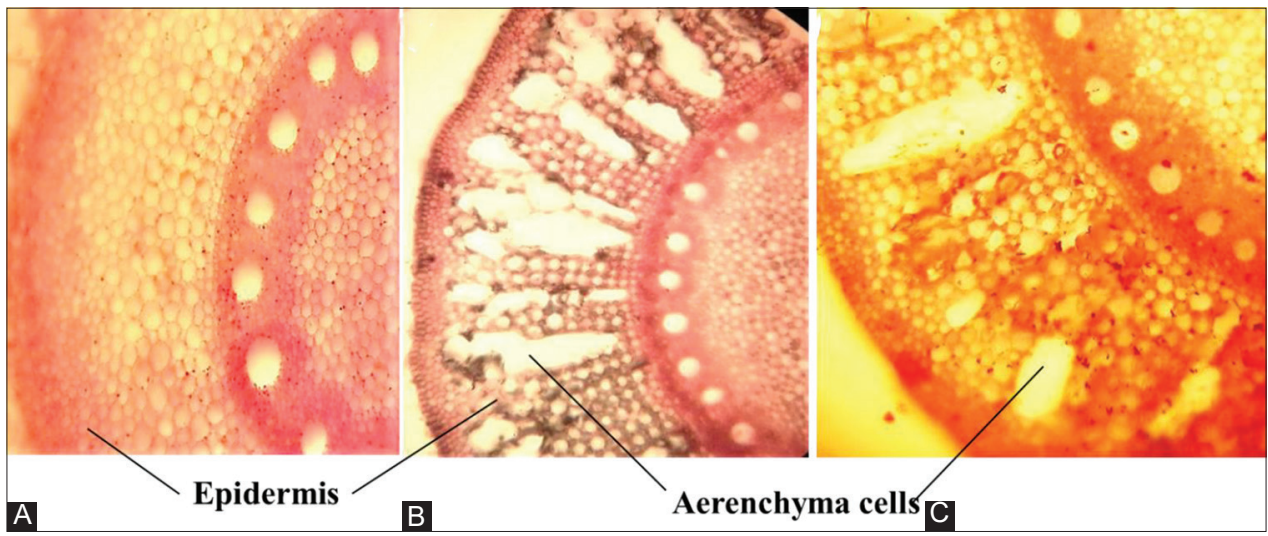

Figure 6: Cross sections of roots of maize plants (A) cross-section of roots of BHM-14 grown without waterlogging (control), (B) cross-section of roots of tolerant BHM-14 grown under waterlogging condition showing presence of large number of aerenchyma cells, (C) cross-section of roots of susceptible BM-7 genotype grown under waterlogging condition showing presence of a few aerenchyma cells 


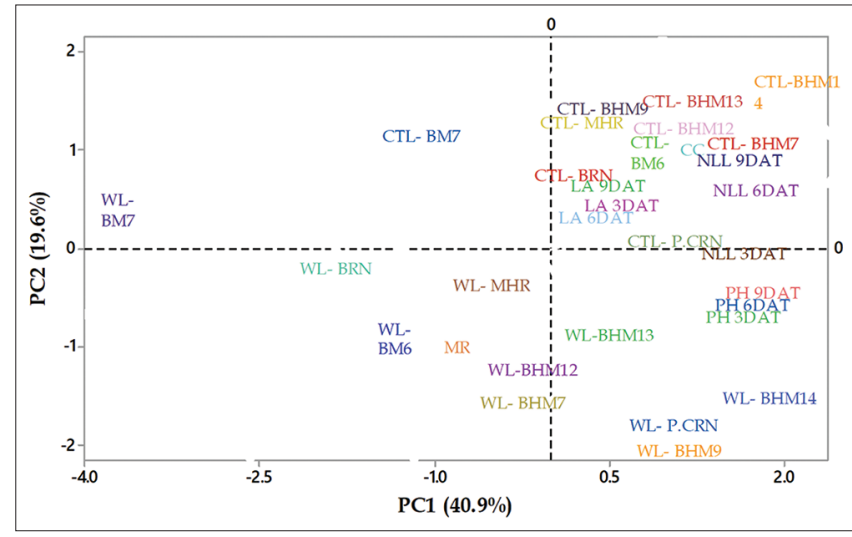

Figure 7: Biplot for Principal Component Analysis of studied important morphological traits of ten maize genotypes under no water (control) and waterlogging treatments. Here, WL: waterlogging, CTL: Control, PH 3DAT: Plant height at 3 days after waterlogging, PH 6DAT: Plant height at 6days after waterlogging, PH 9DAT: Plant height at 9days after waterlogging, NLL 3DAT: Number of live leaves at 3 days after waterlogging, NLL 6DAT: Number of live leaves at 6 days after waterlogging, NLL 9DAT: Number of live leaves at 9 days after waterlogging, MR: percent (\%) leaf mortality rate, LA 3DAT: Leaf area at 3 days after waterlogging, LA 6DAT: Leaf area at 6 days after waterlogging, LA 9DAT: Leaf area at 9 days after waterlogging CC: Chlorophyll content, P. Corn: Popcorn, MHR: Mohor, BRN: Bornali

\section{Total Number of Live Leaves}

In the process of surviving under stress conditions, the plants often shed their live leaves. The anoxic condition around the root caused by waterlogging has the major adverse effect (Dennis et al., 2000). The affected leaves become yellow and stomata close. After waterlogging, the leaf growth rate slows down and leaves became yellow from bottom towards the top. Some leaves turn into yellow and die and sometimes the entire plant dies (Mano et al. 2002). A gradual decreasing trend of number of the live leaves in susceptible genotypes was found in this study (Figure S4, S5, 4A). This result was in agreement with the findings of Vwioko et al. (2017) as the reduction of leaves of maize plants started after one week of waterlogging and gradually all plants loss their leaves and eventually the wilting of the apical portion became apparent.

\section{Percent Leaf Mortality Rate}

In the present experiment, a high rate of leaf mortality was observed and the highest mortality rate was found in the susceptible genotype BHM-7 (Figure 4B). The highest rate of mortality in BHM-7 indicated that due to the stress condition roots of the susceptible plants cannot transport water and nutrients resulting in the death of plants (Figure 4B). Since the roots are unable to efficiently transport water and nutrients under hypoxic or anoxic conditions, shoot functions are affected and visible symptoms such as wilting, senescence and death can be observed (Sasidharan \& Voesenek, 2015). Vwioko et al. (2017) found that the number of surviving maize plants under the treatment decreased as the duration of the waterlogged condition progressed.

\section{Chlorophyll Content}

Chlorophyll is a major component of the chloroplast that has a positive relationship with photosynthesis (Anjum et al., 2011). One of the first stress symptoms, which may be related to nitrogen deficiency caused by leaching and de-nitrification of soil nitrogen has been identified as a significant decrease in leaf chlorophyll content under water-logging stress (Zaidi \& Singh, 2001). In this experiment, the highest decrease of chlorophyll was found in the susceptible genotype BHM-7 (Figure 4C). The same agreement was found in the experiment of Lone et al. (2009) that the relative greenness of leaf was also affected due to flooding treatment as there was fading of leaf color in most of the cases as reflected by their corresponding SPAD values (relative greenness).

\section{Impact on Anatomical Structure}

Aerenchyma formation under waterlogging stress is a remarkable anatomical modification. Aerenchyma is the oxygen storage area that facilitates the movement of gas in the root cortex and thus facilitates aerobic respiration in submerged organs (Mano $\&$ Omori, 2013). Once the tubes form between the roots and shoots, cell metabolism can be oxygenated and maintained. A large number of species including maize can form aerenchyma in the shoots and roots (He et al., 1996a). In this experiment, we found differences in root anatomical structure between two treatments and the tolerant genotypes produced a large number of aerenchyma cells compared to susceptible genotypes (Figure 6). Aerenchyma is related to hydraulic conductivity in roots, where the absorption of water and nutrients can occur even at a lower rate (Irfan et al., 2010). The role of antioxidant and cell wall loosening enzymes in the formation of aerenchyma in Saracura maize (Zea mays L.) roots with contrasting tolerance to waterlogging revealed that long-term stress improves the activity of enzymes involved in loosening the cell wall, linked to a more effective defense of antioxidants (De Souza et al., 2017). Plants in their roots showed constitutive aerenchyma, and it is known that these structures are associated with greater tolerance to excess water (Imaz et al., 2013; Mano \& Omori, 2013).

\section{Impact of Waterlogging on Biochemical Traits}

Naturally, plants face various kinds of biotic and abiotic stresses due to changes in biochemical components that cause changes in their metabolic system. According to Jaiswal (2018), under waterlogging conditions increased APX content has been found. In order to protect the cells from detrimental effects, an enzyme such as APX is essentially needed to scavenge ROS or regenerate antioxidants. To detoxify $\mathrm{H}_{2} \mathrm{O}_{2}$, APX as an isoenzyme is more effective as it is widely distributed inside the cells of higher plants (Shigeoka et al., 2002). In the present study, APX content was greatly increased in tolerant genotypes in treated condition compared to control (Figure 5A).

In response to biotic/abiotic stresses, peroxidase synthesis and accumulation are mostly stimulated in plants (Giorgi et al., 2009). Yadav et al. (2017) found that with the increase in the 
duration of waterlogging, POD activity gradually increased and resistant genotype reported higher POD activity in response to waterlogging stress compared to sensitive genotype. POD is responsible for the scavenging of $\mathrm{H}_{2} \mathrm{O}_{2}$ generated under oxidative stress. Thus, in resistant genotype, these enzymes eliminate the excess $\mathrm{H}_{2} \mathrm{O}_{2}$ more effectively and confer resistance to waterlogging stress. The genotypes that either have better ability to detoxify reactive oxygen species enzymatically (POD) or nonenzymatically or produce less reactive oxygen species are reported to be resistant to waterlogging stress (Lin et al., 2004). In the present investigation, the highest increase of POD was observed in tolerant genotype BHM-13 (Figure 5B) which indicates that this genotype was relatively tolerant to waterlogging stress.

Abiotic stresses have led to excessive generation of ROS, such as $\mathrm{H}_{2} \mathrm{O}_{2}$ (Polle, 2001). These ROS are highly reactive in nature that causes harm to a variety of cellular molecules and metabolites (Ashraf, 2009). According to Yadav et al. (2017), after imposing waterlogging stress, the level of hydrogen peroxide $\left(\mathrm{H}_{2} \mathrm{O}_{2}\right)$ increased in both resistant and sensitive maize genotypes, but the sensitive genotype revealed relatively higher $\mathrm{H}_{2} \mathrm{O}_{2}$ content under waterlogging condition. In the present investigation, the highest increase of $\mathrm{H}_{2} \mathrm{O}_{2}$ was observed in BM-6 (Figure 5C) that indicates it was more susceptible to waterlogging stress because it has a lower scavenging capacity.

\section{CONCLUSION}

In the rice-based cropping system, maize (Z. mays L.) has become an important cereal crop due to its high productivity and suitability for cultivation in most areas. This study investigated traits related to waterlogging tolerance and their response due to treatment at the vegetative stage. Plant height was increased in BHM-14 and BHM-9 compared to control under waterlogging conditions. The total number of live leaves was decreased mostly in the susceptible genotype BM-7 and BM-6 and chlorophyll content was decreased in the susceptible genotype BHM-7 under waterlogging stress compared to control. The biochemical analysis showed that the tolerant genotypes exhibited greater enzymatic activities of APX and POD and accumulated lower content of $\mathrm{H}_{2} \mathrm{O}_{2}$ under waterlogging stress compared to control. The result suggested that the genotypes BHM-9, BMH-13 and BHM-14 exhibited higher waterlogging tolerance whereas BM6, BM-7 and BHM-7 exhibited susceptibility to waterlogging stress. However, the experiment was conducted with only 10 maize genotypes. Further studies with more genetically diverse populations can elucidate and confirm the results of this study.

\section{FUNDING}

This research was supported by the Ministry of Science and Technology, Government of the Peoples' Republic of Bangladesh (Project no. 2020/6/MoST).

\section{ACKNOWLEDGEMENTS}

We acknowledge Bangladesh Agricultural Research Institute for providing seeds of maize.

\section{AUTHOR CONTRIBUTIONS}

AHKR and LH conceived and designed the study. SNA executed all experiments, analyzed the data and wrote the manuscript. SA and NS assisted with biochemical analysis. AHKR critically revised the manuscript.

\section{CONFLICTS OF INTEREST}

The authors declare no conflicts of interest for this study.

\section{REFERENCES}

Abbasi, H. K., Zablotowicz, R. M., Shier, W. T., Jhonson, B. J., Phillis, N. A., Weaver, M. A., Abel, C. A., \& Bruna, H. A. (2015). Aflatoxin and Fumonisin in Corn (Zea mays L.) Infected by Common Smut Ustilago maydis. Plant Disease, 99, 1236-1240. https://doi.org/10.1094/PDIS03-14-0234-RE

Alscher, R. G., Donahue, J. L., \& Cramer, C. L. (1997). Reactive oxygen species and antioxidants: relationship in green cells. Physiologia Plantarum, 100, 224-233. https://doi.org/10.1111/j.1399-3054.1997. tb04778.x

Amin, M. N., Amiruzzaman, M., Ahmed, A., \& Ali, M. R. (2014). Combining ability study in waterlogged tolerant maize (Zea mays L.). Bangladesh Journal of Agricultural Research, 39, 283-291. https://doi.org/10.3329/ bjar.v39i2.20430

Anjum, S. A., Wang, L., Farooq, M., Khan, I., \& Xue, L. (2011a). Methyl jasmonate-induced alteration in lipid peroxidation, antioxidative defence system and yield in soybean under drought. Journal of Agronomy and Crop Science, 197, 296-301. https://doi.org/10.1111/ j.1439-037X.2011.00468.x

Arif, M. R., Islam, M. T., \& Robin, A. H. K. (2019). Salinity stress alters root morphology and root hair traits in Brassica napus. Plants, 8, 192. https://doi.org/10.3390/plants8070192

Ashraf, M. (2009). Biotechnological approach of improving plant salt tolerance using antioxidants as markers. Biotechnology Advances, 27. 84-93. https://doi.org/10.1016/j.biotechadv.2008.09.003

Bailey-Serres, J., \& Voesenek, L. A. C. J. (2008). Flooding stress: acclimations and genetic diversity. Annual Review of Plant Biology, 59, 313-339. https://doi.org/10.1146/annurev.arplant.59.032607.092752

Biswas, J.C., \& Kalra, N. (2018). Effect of Waterlogging and Submergence on Crop Physiology and Growth of Different Crops and Its Remedies: Bangladesh Perspectives. Saudi Journal of Engineering and Technology, 3, 315-328.

Bray, E.A., Bailey-Serres, J. and Weretilnyk, E. (2000) Responses to abiotic stress. Biochemistry \& molecular biology of plants. In W. Gruissem \& R. Jones (Eds.) American Society of Plant Physiologists (1158-1203) Rockville.

Capon, S. J., James, C. S., Williams, L., \& Quinnc, G. P. (2009). Responses to flooding and drying in seedlings of a common Australian desert floodplain shrub: Muehlenbeckia florulenta Meisn. Environmental and Experimental Botany, 66, 178-185. https://doi.org/10.1016/j. envexpbot.2009.02.012

Colmer, T, D., \& Voesenek, L. A. C. (2009). Flooding tolerance: suites of plant traits in variable environments. Functional Plant Biology, 36, 665-681. https://doi.org/10.1071/FP09144

de Azevedo, N. A. D., Prisco, J. T., Eneas, F. J., de Abreu, C, E, B., \& Gomes, F. E. (2006). Effect of salt stress on antioxidative enzymes and lipid peroxidation in leaves and roots of salt tolerant and salt-sensitive maize genotypes. Environmental and Experimental Botany, 56, 87-94. https://doi.org/10.1016/j.envexpbot.2005.01.008

De Souza, K. R. D., de Oliveira, S. M., Andrade, C. A., da Silva, D. M., Campos, N. A., \& Alves, J. D. (2017). Aerenchyma formation in the initial development of maize roots under waterlogging. Theoretical and Experimental Plant Physiology, 29(4), 165-175. https://doi. org/10.1007/s40626-017-0092-z

Dennis, E. S., Dolferus, R., Ellis, M., Rahman, M., Yu, Y., Hoeren, F. U. \& Peacock, W. J. (2000). Molecular strategies for improving waterlogging tolerance in plants. Journal of Experimental Botany, 51, 89-97. https://doi.org/10.1093/jexbot/51.342.89 
DHCP (Digital Herbarium of Crop Plants) (2017). Department of Crop Botany, Bangabandhu Sheikh Mujibur Rahman Agricultural University. http://baritechnology.org/en/home/tech commodity\#result

Du, H., Zhu, J., Su, H., Huang, M., Wang, H., Ding, S., Zhang, B., Luo, A., Wei, S., Tian, X., \& Xu, Y. (2017). Bulked Segregant RNA-seq Reveals Differential Expression and SNPs of Candidate Genes Associated with Waterlogging Tolerance in Maize. Frontires in Plant Science, 8(1022), 1-13. https://doi.org/10.3389/fpls.2017.01022

Fiedler, S., Vepraskas, M. J., \& Richardson, J. L. (2007). Soil redox potential: importance, field measurements, and observations. Advances in Agronomy, 94, 2-56. https://doi.org/10.1016/S0065-2113(06)94001-2

Giorgi, A., Mingozzi, M., Madeo, M., Speranza, G., \& Cocucci, M. (2009). Effect of nitrogen starvation on the phenolic metabolism and antioxidant properties of yarrow (Achillea collina Beckerex Rchb.). Food Chemistry, 14, 204-211. https://doi.org/10.1016/j. foodchem.2008.09.039

He, C. J., Finlayson, S. A., Jordan, W. R., \& Morgan, P. W. (1996 a). Ethylene biosynthesis during aerenchyma formation in roots of maize subjected to mechanical impedance and hypoxia. Plant Physiology, 112, 1679-1685. https://doi.org/10.1104/pp.112.4.1679

Imaz, J. A., Gime'nez, D. O., Grimoldi, A. A., \& Stiker, G. G. (2013). The effects of submergence on anatomical, morphological and biomass allocation responses of tropical grasses Chloris gayana and Panicum coloratum at seedling stage. Crop and Pasture Science, 63, 11451155. https://doi.org/10.1071/CP12335

Imlay, J. A. (2003). Pathways of oxidative damage. Annual Review of Microbiology, 57, 395-418. https://doi.org/10.1146/annurev. micro.57.030502.090938

Irfan, M., Hayat, S., Hayat, O., Afroz, S., \& Ahmad, A. (2010). Physiological and biochemical changes in plants under waterlogging. Protoplasma, 241, 3-17. https://doi.org/10.1007/s00709-009-0098-8

Jackson, M. B., \& Colmer, T. D. (2005). Response and adaptation by plants to flooding stress. Annals of Botany, 96, 501-505. https://doi. org/10.1093/aob/mci205

Jaiswal, A., \& Srivastava, J. P. (2018). Changes in reactive oxygen scavenging systems and protein profiles in maize roots in response to nitric oxide under waterlogging stress. Indian Journal of Biochemistry and Biophysics, 55, 26-33. https://nopr.niscair.res.in/ handle/123456789/44017

KSU (2018). Kansas state University, Wheat Genetics Resource Center, Electronic lab manual. https://www.k-state.edu/wgrc/electronic lab/ aceto_stain.html

Kuk, Y. I., Shin, J. S., Burgos, N. R, Hwang, T. E., Han, O., \& Cho, B. (2003). Antioxidative Enzymes Offer Protection from Chilling Damage in Rice Plants. Crop Science, 43, 2109-2117. https://doi.org/10.2135/ cropsci2003.2109

Li, J. C., Dong, Q., \& Yu, S. (2001). Effect of waterlogging at different growth stages on photosynthesis and yield of different wheat cultivars. Acta Agronomica Sinica, 27(4), 434-441.

Liao, C. T., \& Lin, C. H. (2001). Physiological adaptation of crop plants to flooding stress. Proceedings of the National Science Council, Republic of China (Part B, Life Sciences), 25 (3), 148- 57.

Lin, K. H. R., Weng, C. C., Lo, H. F., \& Chen, J. T. (2004). Study of the root antioxidative system of tomatoes and egg plants under waterlogged conditions. Plant Science, 167, 355-365. https://doi.org/10.1016/j. plantsci.2004.04.004

Lone A. A. \& Warsi, M. Z. K. (2009). Response of Maize (Zea mays L.) To Excess Soil Moisture (ESM) Tolerance at Different Stages of Life Cycle. Botany Research International, 2(3), 211-217.

Mahesh, N., Gowda, M. V. C., Motagina, B. N., \& Garatna, F. (2013). Correlation and path coefficient analysis of yield and karnel components in maize. Karnataka Journal of Agricultural Science, 26(2), 306-307.

Mano, S., Nakamori, C., Hayashi, M., Kato, A., Kondo, M., \& Nishimura, M. (2002). Distribution and characterization of peroxisomes in Arabidopsis by visualization with GFP: Dynamic morphology and actin-dependent movement. Plant Cell Physiology, 43, 331-341. https://doi.org/10.1093/pcp/pcf037

Mano, Y., Muraki, M., \& Takamizo, T. (2006). Identification of QTL controlling flooding tolerance in reducing soil conditions in maize (Zea mays L.) seedlings. Plant Production Science, 9, 176-181. https://doi. org/10.1626/pps.9.176

Mano, Y., \& Omori, F. (2013). Relationship between constitutive root aerenchyma formation and flooding tolerance in Zea nicaraguensis.
Plant Soil, 370, 447-460. https://doi.org/10.1007/s11104-013-1641-0 McKersie, B. D., \& Leshem, Y. (1994). Stress and Stress Coping in Cultivated Plants. Dordrecht: Kluwer Academic Publishes.

Nakano, Y., \& Asada, K. (1981). Hydrogen peroxide is scavenged by ascorbate-specific peroxidase in spinach chloroplasts. Plant Cell Physiology, 22(5), 867-880. https://doi.org/10.1093/oxfordjournals. pcp.a076232

Osman, K. A., Tang, B., Wang, Y., Chen, J., Yu, F., Li, L., Han, X., Zhag, Z. Yan, J., Zheng, Y., You, B., \& Qiu, F. (2013). Dynamic QTL Analysis and Candidate Gene Mapping for Waterlogging Tolerance at Maize Seedling Stage. PLOS ONE, 8(11), e79305. https://doi.org/10.1371/ journal.pone.0079305

Parent, C., Capelli, N., Berger, A., Cravecoeur, M., \& Dat, J. F. (2008). An overview of plant responses to soil waterlogging. Plant Stress, 2 20-27.

Pezeshki, S. R. (2001). Wetland plant responses to soil flooding. Environmental Experimental Botany, 46, 299-312. https://doi. org/10.1016/S0098-8472(01)00107-1

Polle, A. (2001). Dissecting the superoxide dismutase-ascorbateglutathionepathway in chloroplasts by metabolic modeling: computer simulations as a step towards flux analysis. Plant Physiology, 126, 445- 462. https://doi.org/10.1104/pp.126.1.445

Ren, B., Zhang, J., Li. X., Fan, X., Dong, S., Liu, P., \& Zhao, B. (2014). Effects of waterlogging on the yield and growth of summer maize under field conditions. Canadian Journal of Plant Science, 94, 23-31. https://doi. org/10.4141/cjps2013-175

Sasidharan, R., \& Voesenek, L. A. C. J. (2015). Ethylene-mediated acclimations to flooding stress. Plant Physiology, 169, 3-12. https:// doi.org/10.1104/pp.15.00387

Shigeoka, S., Ishikawa, T., Tamoi, M., Miyagawa, Y., Takeda, T, Yabuta., \& Yoshimura, K. (2002). Regulation and function of ascorbate peroxidase isoenzymes. Journal of Experimental Botany, 53, 13051319. https://doi.org/10.1093/jexbot/53.372.1305

Shiono, K., Ogawa, S., Yamazaki, S., Isoda, H., Fujimura, T., Nakazono, M., \& Colmer, T. D. (2011). Contrasting dynsamics of radical $\mathrm{O}_{2}$-loss barrier induction and aerenchyma formation in rice roots of two lengths. Annals of Botany, 91, 255-261. https://doi.org/10.1093/aob/mcq221

Subbaiah, C. C., \& Sachs, M. M. (2003). Molecular and cellular adaptations of maize to flooding stress. Annals of Botany, 90, 119-127. https:// doi.org/10.1093/aob/mcf210

Suralta, R. R., \& Yamauchi, A. (2008). Root growth, aerenchyma development, and oxygen transport in rice genotypes subjected to drought and waterlogging. Environmental Experimental Botany, 64 5-82. https://doi.org/10.1016/j.envexpbot.2008.01.004

Velikova, V., Yordancv, I., \& Edreva, A. (2000). Oxidative stress and some antioxidant systems in acid rain-treated bean plants. Protective role of exogenous polyamines. Plant Science, 151, 59-66. https://doi. org/10.1016/S0168-9452(99)00197-1

Vwioko, E., Adinkwu, O., \& El-Esawi, M. A. (2017). Comparative Physiological, Biochemical, and Genetic Responses to Prolonged Waterlogging Stress in Okra and Maize Given Exogenous Ethylene Priming. Frontiers in Physiology, 8, 632. https://doi.org/10.3389/ fphys.2017.00632

Yadav, D. K., \& Srivastava. J. P. (2017). Temporal Changes in Biochemical and Antioxidant Enzymes Activities in Maize (Zea mays L.) under Waterlogging Stress during Early Growth Stage. International Journal of Current Microbiology and Applied Sciences, 6, 351-362. https:// doi.org/10.20546/ijcmas.2017.606.041

Zaidi, P. H., Maniselvan, P., Srivastava, A., Singh, R. P., Singh, N. N., Srinivasan, G. (2007a). Association between line per se and hybrid performance under excessive soil moisture stress in tropical maize (Zea mays L.). Field Crops Research, 101, 117-126. https://doi. org/10.1016/j.fcr.2006.10.002

Zaidi, P. H., Mehrajuddin, Jat, M. L., Pixley, K., Singh, R. P., Dass, S. (2008, October 20-23). Resilient maize for improved and stable productivity of rain-fed environment of South and South-East Asia.: Maize for Asia - Emerging Trends and Technologies. Proceeding 10 ${ }^{\text {th }}$ Asian Regional Maize Workshop, Makassar, Indonesia.

Zaidi, P. H., Rafique, S., Rai, P. K., Singh, N. N., \& Srinivasan, G. (2004) Tolerance to excess moisture in maize (Zea mays L.): Susceptible crop stages and identification of tolerant genotypes. Fie/d Crops Research, 90(2-3), 189-202. https://doi.org/10.1016/j. fcr.2004.03.002

Zaidi, P. H., Rafique, S., \& Singh, N. N. (2003). Response of maize (Zea mays 
L.) genotype to excess moisture stress: morpho-physiological effects and basis of tolerance. European Journal of Agronomy, 19, 383-399. https://doi.org/10.1016/S1161-0301(02)00090-4

Zaidi, P. H., \& Singh, N. N. (2001). Effect of water-logging on growth, biochemical compositions and reproduction in maize. Journal of Plant Biology, 28, 61-69.

Zaidi, P, H., Singh, N, N., (2002). Identification of morpho-physiological traits for excess soil moisture tolerance in maize. In K. K. Bora, K. Singh, A. Kumar (Eds.), Stress and Environmental Physiology (pp. 172-183 Jodhpur, India: Scientific publishers.

Zhang, Z. X., Jiang, H. W., Wei, Z. Y., \& Zheng, Y. L. (2003). Study on enzymology in root of maize inbred after waterlogging stress. Hubei Agricultural Science, 1 (3), 25-27. https://europepmc.org/article/ cba/564455\#abstract 


\section{SUPPLEMENTARY MATERIALS}

Table S1: Analysis of variance for morphological and biochemical traits of ten maize genotypes under control and waterlogging treatments

\begin{tabular}{|c|c|c|c|c|c|c|c|c|c|}
\hline \multirow[t]{2}{*}{ Traits } & \multicolumn{3}{|c|}{$\mathrm{df}$} & \multicolumn{3}{|c|}{ F value } & \multicolumn{3}{|c|}{$P$ value } \\
\hline & Treatment $(\mathrm{T})$ & Genotype (G) & $T \times G$ & Treatment $(\mathrm{T})$ & Genotype (G) & $T \times G$ & Treatment $(\mathrm{T})$ & Genotype (G) & $T \times G$ \\
\hline PH 3DAT & 1 & 9 & 9 & 7.73 & 10.55 & 3.28 & 0.006 & $<0.001$ & $\overline{<0.001}$ \\
\hline PH 6DAT & 1 & 9 & 9 & 4.8 & 10.01 & 3.12 & 0.029 & $<0.001$ & $<0.001$ \\
\hline PH 9DAT & 1 & 9 & 9 & 1.1 & 9.01 & 2.15 & 0.295 & $<0.001$ & 0.026 \\
\hline NL 3DAT & 1 & 9 & 9 & 0.2 & 12.89 & 1.54 & 0.657 & $<0.001$ & 0.135 \\
\hline NL 6DAT & 1 & 9 & 9 & 52.72 & 9.39 & 0.75 & $<0.001$ & $<0.001$ & 0.663 \\
\hline NL 9DAT & 1 & 9 & 9 & 143.62 & 5.63 & 1.52 & $<0.001$ & $<0.001$ & 0.141 \\
\hline$\% \mathrm{MR}$ & 1 & 9 & 9 & 571.13 & 3.12 & 1.59 & $<0.001$ & $<0.001$ & 0.12 \\
\hline $\mathrm{CC}$ & 1 & 9 & 9 & 119.14 & 3.14 & 3.28 & $<0.001$ & $<0.001$ & $<0.001$ \\
\hline LA 3DAT & 1 & 9 & 9 & 0.89 & 3.76 & 0.61 & 0.352 & 0.002 & 0.78 \\
\hline LA 6DAT & 1 & 9 & 9 & 1.26 & 2.96 & 1.35 & 0.268 & 0.009 & 0.245 \\
\hline LA 9DAT & 1 & 9 & 9 & 2.24 & 4.81 & 1.05 & 0.142 & $<0.001$ & 0.421 \\
\hline $\mathrm{H}_{2} \mathrm{O}_{2}$ & 1 & 3 & 3 & 55568.96 & 12475.5 & 17505.52 & $<0.001$ & $<0.001$ & $<0.001$ \\
\hline POD & 1 & 3 & 3 & 8117.81 & 798.66 & 971.81 & $<0.001$ & $<0.001$ & $<0.001$ \\
\hline$A P X$ & 1 & 3 & 3 & 4225.55 & 3693.58 & 1559.52 & $<0.001$ & $<0.001$ & $<0.001$ \\
\hline
\end{tabular}

$\mathrm{df}=$ Degrees of freedom, $\mathrm{P}=$ Probability of statistical significance, $\mathrm{TX} \mathrm{G}=$ Treatment genotype interaction, $\mathrm{PH}$ 3DAT= plant height at 3days, $\mathrm{PH}$ 6DAT= plant height at 6days, PH 9DAT = plant height at 9days, NL3DAT = total number of live leaves at 3days, NL 6DAT = total number of live leaves at 6days, NL 9DAT = total number of live leaves at 9 days, $\% M R=$ percent $(\%)$ mortality rate, $C C=$ chlorophyll rate, LA 3DAT $=$ total leaf area at 3days, $L A$ 6DAT $=$ total leaf area at 6days, $L A 9 D A T=$ total leaf area at 9days, $\mathrm{H}_{2} \mathrm{O}_{2}=$ hydrogen peroxide, $\mathrm{POD}=$ peroxidase, $\mathrm{APX}=$ ascorbate peroxidase

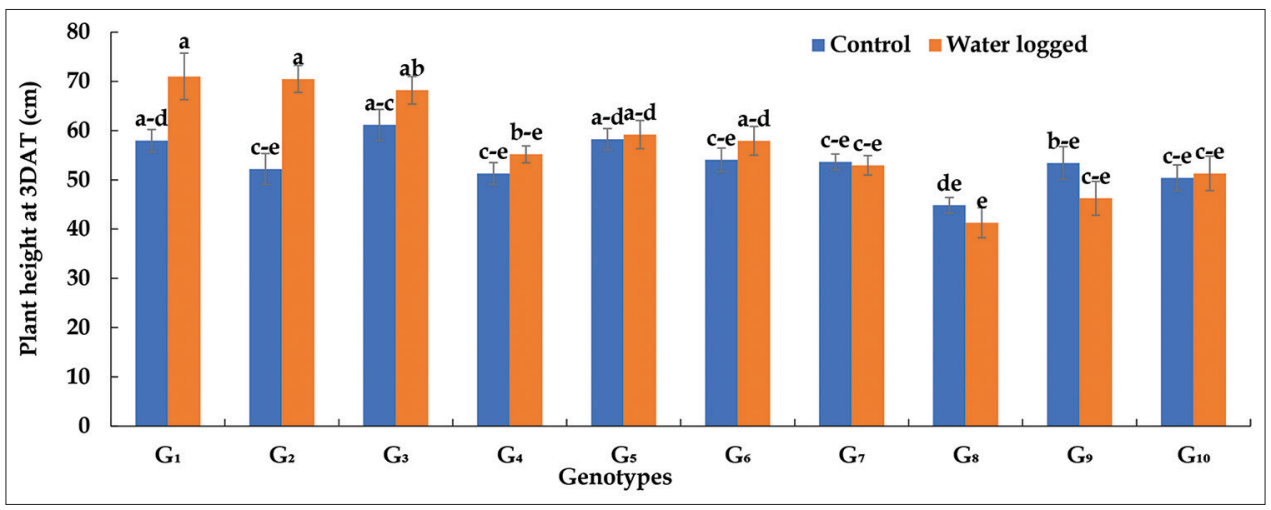

Figure S1: Treatment effect, genotype variation and treatment $\times$ genotype interaction for plant height at three days after waterlogging of ten maize genotypes under control and waterlogging treatments. Vertical bars indicate standard error of mean; different letters indicate significant difference among the treatment $\times$ genotype interaction. In the graph, G1=BHM-14, G2=BHM-9, G3= Popcorn, G4=BHM-13, G5= BHM-7, G6= BHM-12, G7= BM-6, G8= BM-7, G9= Mohor, G10= Barnali

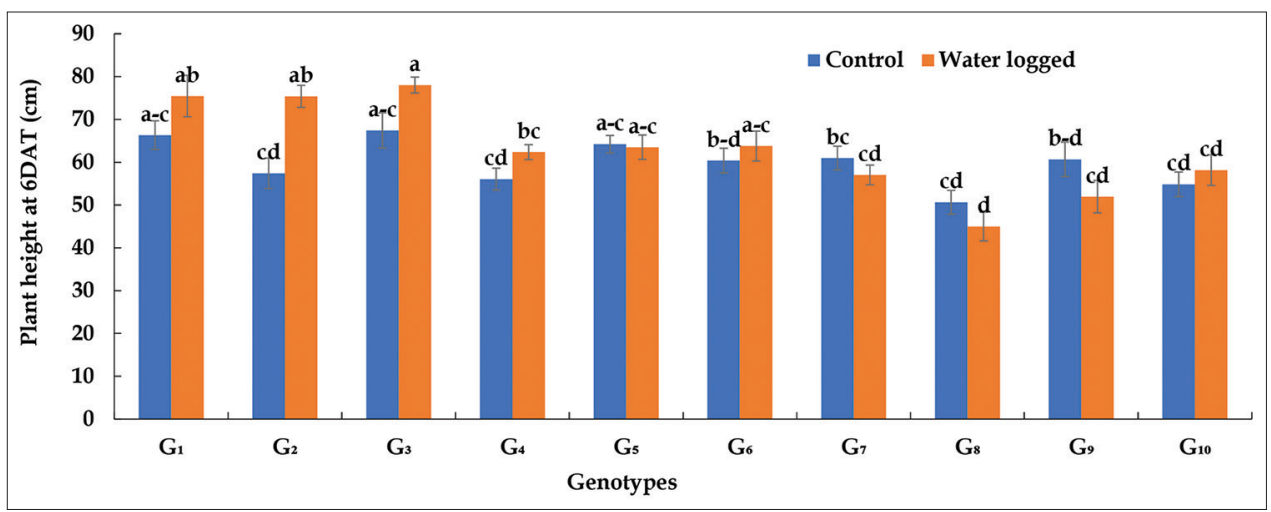

Figure S2: Treatment effect, genotype variation and treatment $\times$ genotype interaction for plant height at six days after waterlogging of ten maize genotypes under control and waterlogging treatments. Vertical bars indicate standard error of mean; different letters indicate significant difference among the treatment $\times$ genotype interaction. In the graph, G1=BHM-14, G2=BHM-9, G3= Popcorn, G4= BHM-13, G5= BHM-7, G6= BHM-12, G7 = BM-6, G8= BM-7, G9= Mohor, G10= Barnali 


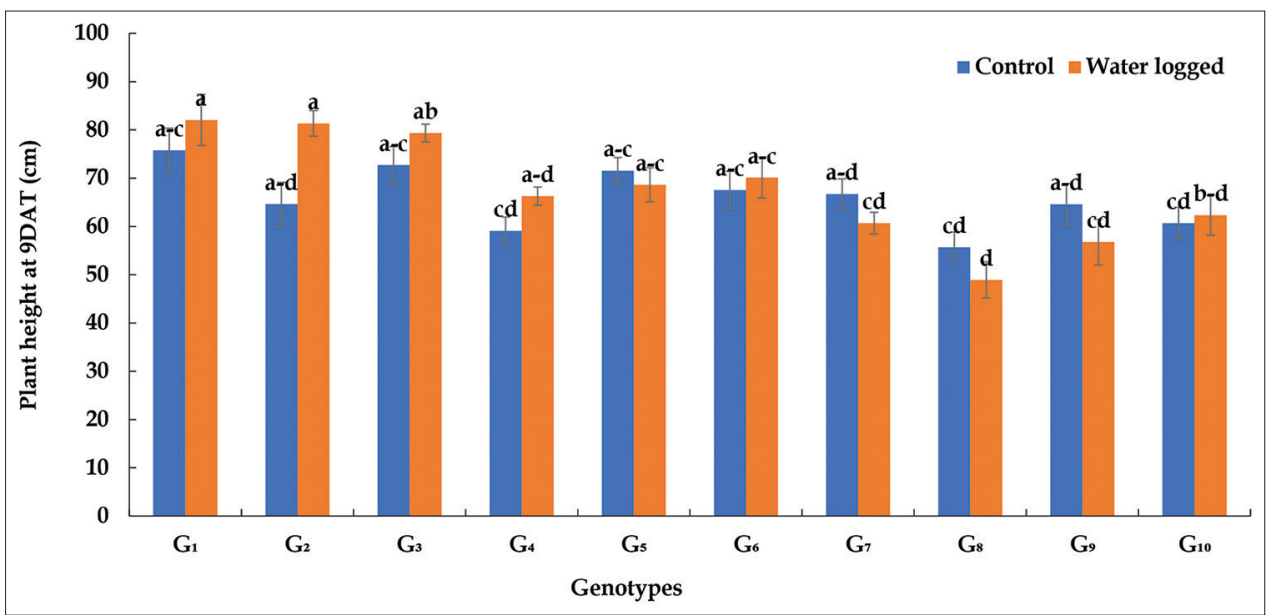

Figure S3: Treatment effect, genotype variation and treatment $\times$ genotype interaction for plant height at nine days after waterlogging of ten maize genotypes under control and waterlogging treatments. Vertical bars indicate standard error of mean; different letters indicate significant difference among the treatment $\times$ genotype interaction. In the graph, G1=BHM-14, G2=BHM-9, G3= Popcorn, G4=BHM-13, G5= BHM-7, G6= BHM-12, $\mathrm{G} 7=\mathrm{BM}-6, \mathrm{G} 8=\mathrm{BM}-7, \mathrm{G} 9=$ Mohor, G10 = Barnali

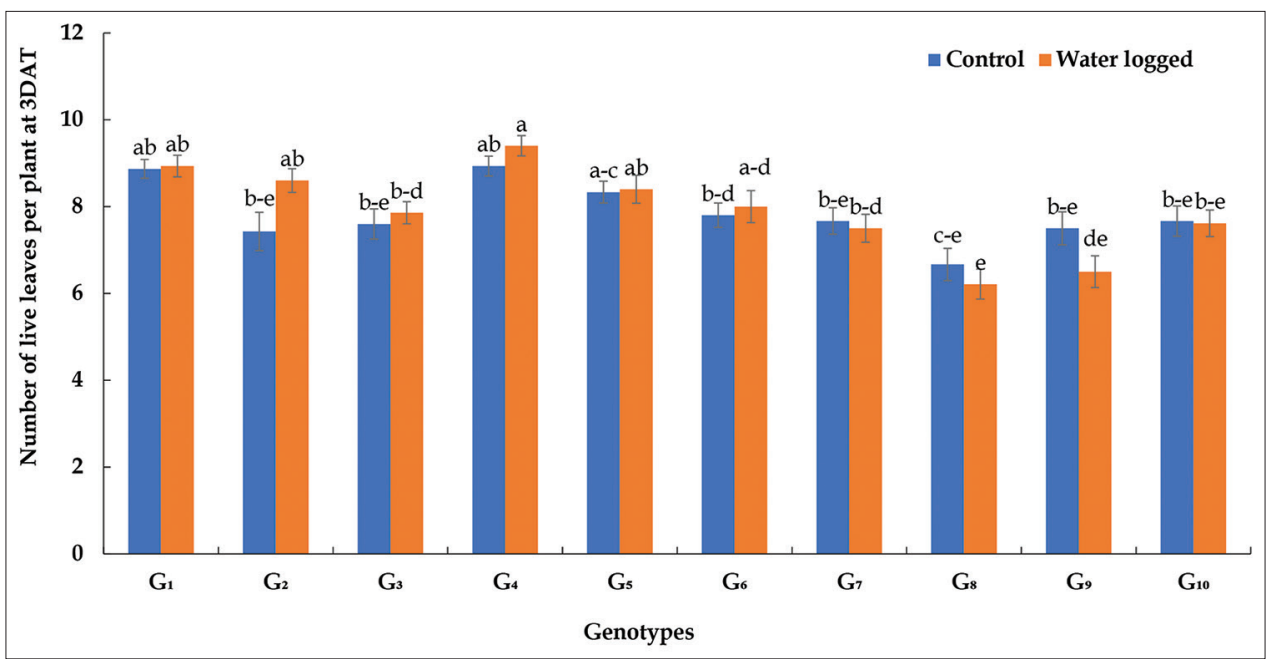

Figure S4: Treatment effect, genotype variation and treatment $\times$ genotype interaction for total number of live leaves at three days after waterlogging of ten maize genotypes under control and waterlogging treatments. Vertical bars indicate standard error of mean; different letters indicate significant difference among the treatment $\times$ genotype interaction. In the graph, G1= BHM-14, G2= BHM-9, G3= Popcorn, G4= BHM-13, G5= BHM-7, G6= BHM-12, G7= BM-6, G8= BM-7, G9= Mohor, G10= Barnali 


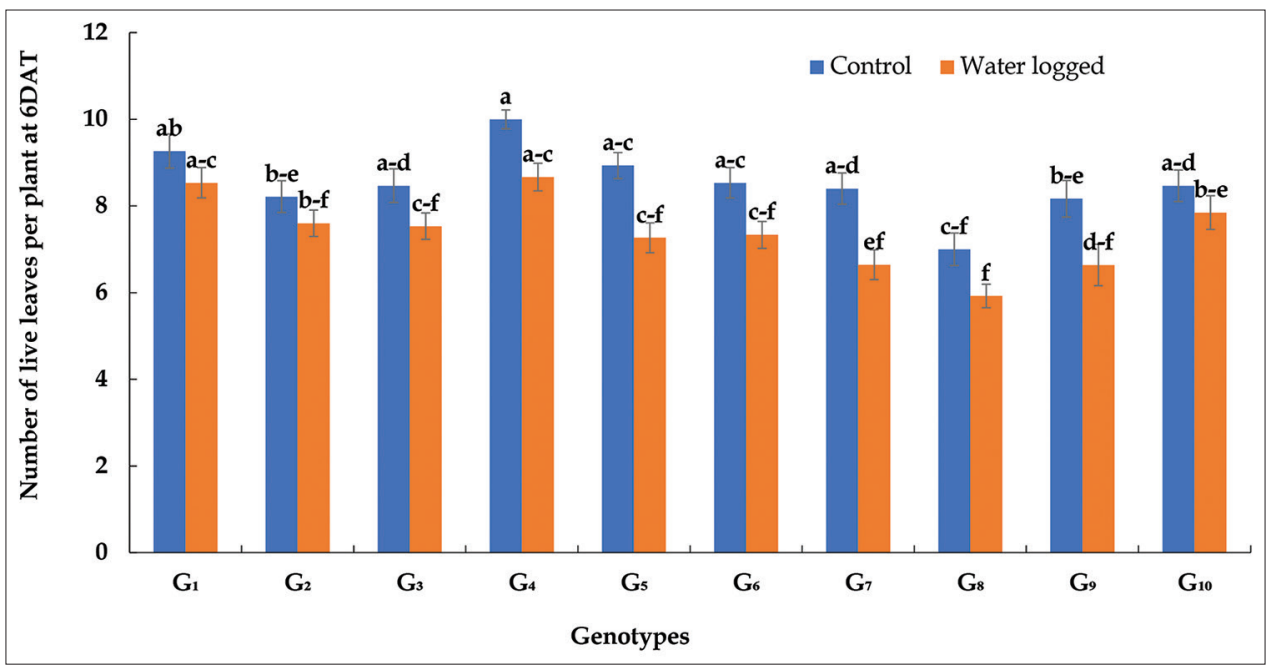

Figure S5: Treatment effect, genotype variation and treatment $\times$ genotype interaction for total number of live leaves at six days after waterlogging of ten maize genotypes under control and waterlogging treatments. Vertical bars indicate standard error of mean; different letters indicate significant difference among the treatment $\times$ genotype interaction. In the graph, G1=BHM-14, G2=BHM-9, G3= Popcorn, G4=BHM-13, G5= BHM-7, G6= BHM-12, G7= BM-6, G8= BM-7, G9= Mohor, G10= Barnali

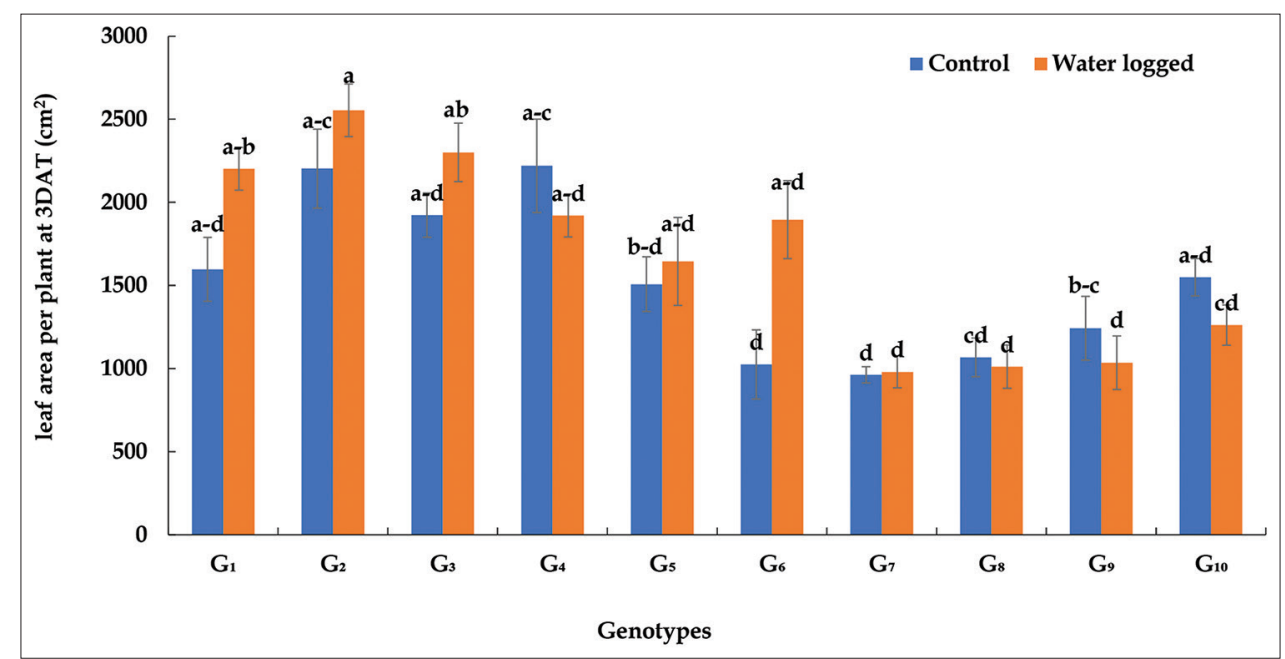

Figure S6: Treatment effect, genotype variation and treatment $\times$ genotype interaction for total leaf area per plant at three days after waterlogging of ten maize genotypes under control and waterlogging treatments. Vertical bars indicate standard error of mean; different letters indicate significant difference among the treatment $\times$ genotype interaction. In the graph, G1=BHM-14, G2=BHM-9, G3= Popcorn, G4= BHM-13, G5= BHM-7, G6= BHM-12, G7= BM-6, G8= BM-7, G9= Mohor, G10= Barnali 


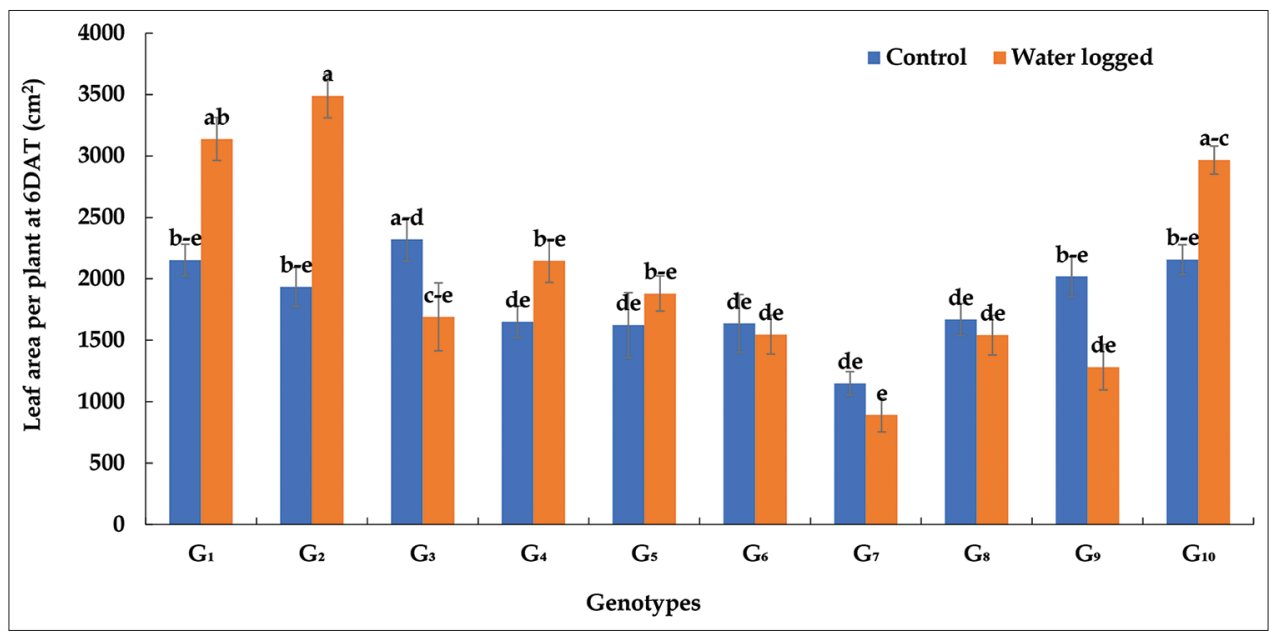

Figure S7: Treatment effect, genotype variation and treatment $\times$ genotype interaction for total leaf area per plant at six days after waterlogging of ten maize genotypes under control and waterlogging treatments. Vertical bars indicate standard error of mean; different letters indicate significant difference among the treatment $\times$ genotype interaction. In the graph, G1=BHM-14, G2=BHM-9, G3= Popcorn, G4= BHM-13, G5= BHM-7, G6= BHM-12, G7= BM-6, G8= BM-7, G9= Mohor, G10= Barnali

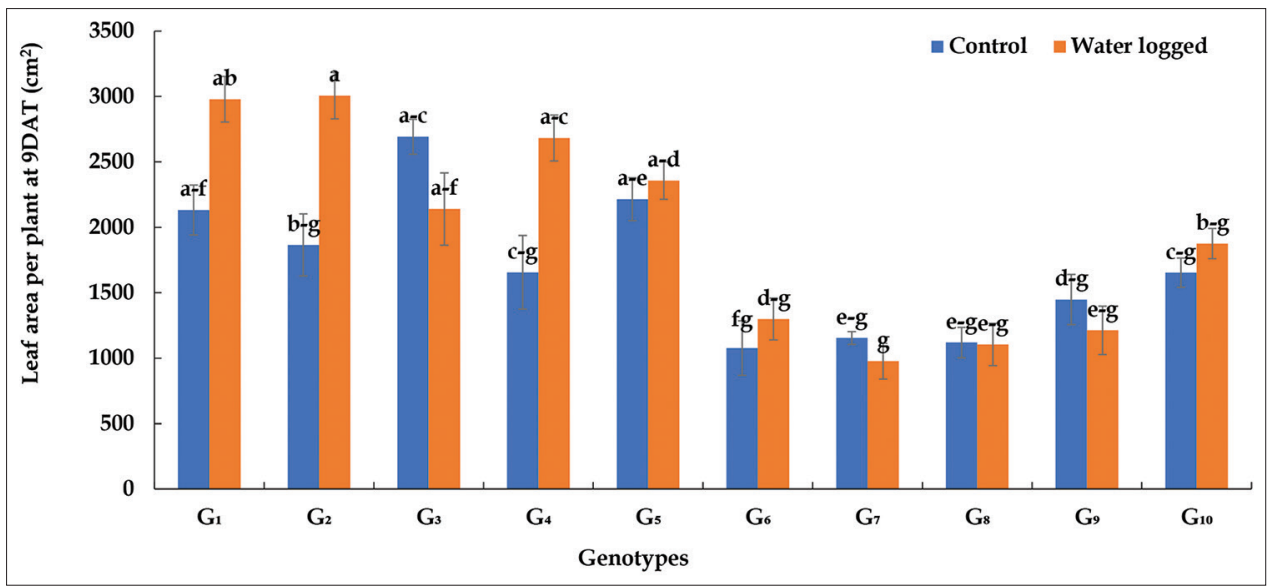

Figure S8: Treatment effect, genotype variation and treatment $\times$ genotype interaction for total leaf area per plant at nine days after waterlogging of ten maize genotypes under control and waterlogging treatments. Vertical bars indicate standard error of mean; different letters indicate significant difference among the treatment $\times$ genotype interaction. In the graph, G1= BHM-14, G2=BHM-9, G3= Popcorn, G4= BHM-13, G5= BHM-7, G6= BHM-12, G7= BM-6, G8= BM-7, G9= Mohor, G10= Barnali 